УДК 78.03(477.83)

DOI https://doi.org/10.32782/facs-2021-1-5

\title{
Руслан КУНДИС
}

заслужений діяч естрадного мистецтва України, доцент кафедри режсисури та хореографії, Львівський національний університет імені Іван Франка, вул. Університетська 1, м. Львів, 79000 ORCID: 0000-0002-6374-4811

Бібліографічний опис статті: Кундис, Р. (2021). Розвиток творчих концепцій М. Оберюхтіна у формуванні професійного баянного мистецтва Дрогобиччини. Fine Art and Culture Studies, 1, 29-36, doi: https://doi.org/10.32782/facs-2021-1-5

\section{РОЗВИТОК ТВОРЧИХ КОНЦЕПЦІЙ М. ОБЕРЮХТІНА У ФОРМУВАННІ ПРОФЕСІЙНОГО БАЯННОГО МИСТЕЦТВА ДРОГОБИЧЧИНИ}

\begin{abstract}
У статті розкривається один із ключових елементів засновника Львівської баянної школи М. Оберюхтіна професіоналізачія мистецького життя регіону у сфері формування баянно-акордеонного мистецтва учнями та послідовниками. Однією із провідних інституцій виступає Дрогобич, у якому домінують пріоритети музикування на баяні-акордеоні в музичному коледжі імені Василя Барвінського та Інституті музичного мистецтва педагогічного університету імені Івана Франка. 3 кониентровано увагу на окремих постатях регіону Ернесту Мантулєву, Роману Пукасу, Сергію Максимову, Валерію Шафеті, Андрію Душному, Василю Гамарі які крізь призму Львівської школи популяризують мистецтво гри на баяні-акордеоні і масштабному колективному музикуванні в Україні та зарубіжжі, здійснюють вагому виконавську, навчально-виховну, науково-методичну й мистецькоорганізаційну діяльність в контексті національної музичної культури.

Ключові слова: Львівська школа, баян-акордеон, творчість, персоналії, колективи, музичний коледж імені Василя Барвінського, кафедра народних інструментів Дрогобищького педагогічного університету імені Івана Франка.
\end{abstract}

\section{Ruslan KUNDYS}

Ukraine Pop Art Honored Worker, Associate Professor of the Department of Directing and Choreography, Lviv Ivan Franko National University, street University 1, Lviv, 79000

ORCID: 0000-0002-6374-4811

To cite this article: Kundys, R. (2021). Rozvytok tvorchykh kontseptsii M. Oberiukhtina u formuvanni profesiinoho baiannoho mystetstva Drohobychchyny [Development of $\mathrm{m}$. oberiukhtin's creative conceptions in formation of professional accordion art in the drohobych land]. Fine Art and Culture Studies, 1, 29-36, doi: https://doi.org/10.32782/facs-2021-1-5

\section{DEVELOPMENT OF M. OBERIUKHTIN'S CREATIVE CONCEPTIONS IN FORMATION OF PROFESSIONAL ACCORDION ART IN THE DROHOBYCH LAND}

The article reveals one of the key performing elements of M. Oberiukhtin, the founder of Lviv Accordion School, as well as the regional professionalization of artistic life of the sphere of formation of bayan-accordion art skills of his pupils and followers. Drohobych Vasyl'Barvinskyi Musical College and Ivan Franko State Pedagogical University's Institute of Musical Art wherein the priorities of accordion playing are dominant, are exemplifi ed as the leading institutions in the fi eld under consideration. Due attention is focussed on the prominent fi gures of Ernest Mantuliev, Roman Pukas, Serhiy Maksymov, Valeriy Shafeta, Andriy Dushnyi, and Vasyl'Hamar, who popularize the art of accordion playing by the principles of the Lviv school, contribute to a collective accordion musical performance within and without Ukraine, and fulfi ll signifi can't performance, educational and scientifi c-methodical work in the context of Ukrainian national musical culture.

Key words: Lviv school, bayan-accordion, creativity, personality, collectives, Vasyl'Barvinskyi Musical College, Chair of Folk Musical Instruments of Ivan Franko State Pedagogical University 
Постановка проблеми. Формування традицій Львівської баянної школи у сфері виконавства, педагогіки та творчості має порівняно недавню історію та невелику дослідницьку статистику. Проте іiі становлення позначене стрімкістю та помітною результативністю, що зробило регіональну школу Львова вагомою складовою української академічної школи народно-інструментального мистецтва. Підвалини іiі гнучкої педагогічної концепціїзапочатковані корифеями: М. Оберюхтіним та його послідовниками - А. Онуфрієнком та Е. Мантулєвим. Цими музичними діячами закладено та створено передумови розбудови багаторівневої мережі фахового викладання гри на баяні у музичних навчальних закладах регіону.

Аналіз досліджень. Теоретичною базою дослідження є роботи українських музикознавців, пов'язані 3 питаннями вітчизняного баянного мистецтва, які охоплюють значне коло методичних, історичних, виконавських проблем, серед них: узагальнюючі праці з історії української школи народно-інструментального мистецтва (М. Давидова [1], Є. Іванова, А. Сташевського, А. Семешка); праці історичного спрямування та довідниково-енциклопедичні видання (М. Імханицького, довідники А. Басурманова, А. Семешка [11], А. Душного та Б. Пица [4; 10], словник I. Лисенка); матеріали конференцій («Львівська баянна школа та iï видатні представники» [6; 7]; «Академічне народно-інструментальне мистецтво та вокальні школи Львівщини»; «Творчість композиторів України для народних інструментів»; «Народно-інструментальне мистецтво на зламі XX - XXI століть»); дослідження окремих мистецьких явищ та розкриття персоналійпредставників осередку баянного мистецтва Львівщини й зокрема Дрогобиччини представлені у роз відках (А. Батршина, В. Балика, В. Власова $[6,20-26]$, В. Голубничого, А. Душного [3; 7, 124-140], М. Імханицького [5], С. Карася, Д. Кужелєва [6, 67-75; 7, 5-10], Е. Мантулєва, М. Михаця [7, 37-45; 8; 9] М. Оберюхтіна [7, 46-64], А. Онуфрієнка, Я. Олексіва, Б. Пица [6, 88-107; 7, 116-132], Л. Посікіри [6, 76-85], М. Римаренка [7, 11-15], А. Славича, І. Фрайта [6, 117-123], Ю. Чумака [6, 124-132], А. Шамігова, В. Шафети [12; 13; 14; 15], О. Якубова, В. Янчака [6, 139-143], О. Яцківа [177] та ін.).
Мета статті - розкрити становлення та розвиток баянно-акордеонного мистецтва Дрогобиччини в контексті Львівської баянної школи на основі випускників та послідовників іiї фундатора Михайла Дмитровича Оберюхтіна.

Виклад основного матеріалу. Михайло Оберюхтін - баяніст-віртуоз і талановитий педагог консерваторії та середньої спеціальної музичної школи-інтернат ім. С. Крушельницької у Львові, наставник потужного грона виконавців, диригентів, діячів музичної науки і педагогіки, автор методичних праць, що узагальнюють досвід педагогіки, звукоутворення, артикуляції, фразування та інтерпретації. Його фаховий підхід у баянному виконавстві та педагогіці зумовили сприйняття цього інструменту не як засобу ідеологічного тиску, уособлення накинутої ззовні, невластивої локальній традиції, панівної системи цінностей, а як органічної складової народно-академічної культури, від якої веде відлік Львівська регіональна інструментальна школа. Концепцію аспект представляє засвоєння глибоко самобутніх освітньофахових, педагогічних, виконавських традицій провідних фахово-освітніх осередків регіону на які проектуються здобутки і напрацювання їх яскравих представників, засновників авторських шкіл: М. Оберюхтіна, А. Онуфрієнка, Е. Мантулєва, та безпосередніх спадкоємців і продовжувачів цілісного комплексу багатовекторної творчої діяльності - С. Карася, А. Душного, Ю. Чумака, Я. Олексіва, що стимулюють поступ і збагачення традиції. Серед таких регіональних центрів популяризації традицій школи виступає Дрогобич - «Мекка народноінструментального (баянно-акордеонного курсив Р. К.) мистецтва України XXI століття» (за М. Давидовим). Важливою складовою Львівської баянної школи $є$ фахові навчальні заклади Дрогобиччини. У їх діяльності, поряд 3 викладацькою функцією, конкурсними успіхами вихованців та педагогіко-методичним напрацюваннями, особливе місце належить ансамблям та оркестрам за участі баянів-акордеонів, які відіграють виняткову роль в мистецькому житті краю, представляють здобутки Львівської баянної школи у численних регіонах України та на зарубіжних концертних естрадах. Функції навчальних виконавських колективів спрямовані на відпрацювання професійних навичок ансамблювання, охоплення обширного 
різностильового репертуару та його інтерпретації в умовах колективного музикування. Однак, як показує практика, діяльність таких колективів виходить далеко за межі фаховометодичних потреб, особливо на рівні музичного життя регіонів. Тут подібні творчі формації стають не лише основним мірилом, але й носієм музичного професіоналізму, засобом забезпечення суспільних запитів, полем для широкої виконавської і творчої діяльності, нерідко у поєднанні зі сміливим експериментуванням. 3 цього погляду цікавим завданням $\epsilon$ аналіз діяльності Дрогобицьких колективів 3 баянами та акордеонами у їх складі (від музичної школи до ВН3) на Львівщині, оскільки вони мають тривалу історію, відрізняються значною різноманітністю форм і складів, широтою сфер реалізації. Тісну спадкоємність традицій Львівської баянної школи демонструють провідні фахівці Дрогобицького музичного училища (сьогодні - коледжу) ім. В. Барвінського. Засновник відділу народних інструментів, випускник Харківської консерваторії А. Бакаєв започаткував оркестр народних інструментів (у 19581960 pp. його очолив А. Вояджіс) - лауреата республіканських конкурсів оркестрів народних інструментів (1965-1967). Перші педагоги відділу - баяністи Медвєдєв та Будьонний виступали у дуеті. У свій час в училищі працювали представники старшого покоління випускників Львівської школи Е. Мантулєв, М. Мамайчук, Р. Пукас. Доречно наголосити, що їхніми зусиллями було створено «Прикарпатське тріо баяністів» (1965-1984), яке поставило перед собою мету пропагувати педагогічний репертуар для музичних училищ $[12 ; 14]$. Колектив, що об'єднав трьох виконавців-солістів та ансамблістів, і водночас профільних педагогів закладу, вів концертну діяльність на Дрогобиччині, у Львові, Рівному, Івано-Франківську, Тернополі. У їх репертуарі були переклади та власні фольклорні обробки. Учасник ансамблю - Роман Пукас - прекрасний виконавець і талановитий педагог, завідував відділом, був заступником директора (1967-1973), і зрештою - директором навчального закладу (19731984). Знаково, що концерт пам'яті визначного музиканта у квітні 2005 року був підготовлений виключно силами баянно-акордеонних класів та за участі однорідного ансамблю під керівництвом Р. Кабала. Ряд викладачів та студентів стали лауреатами різноманітних конкурсних змагань: Н. Гатайло-Мазур, I. Сирватка, М. Паньків, Ю. Чумак, О. Кривозірка, Н. Федина, О. Волянський, Р. Стахнів, І. Онисів, В. Муравський, В. Мицак, Н. Хомин, Л. Шишак, Б. Федишин, В. Сіміонеску, В. Бобанич, В. Салій, П. Щур. Сьогодні свій педагогічний досвід передають молодому поколінню вихованці Львівської консерваторії (тепер музичної академії) - Т. Кисилевич, М. Плекан, С. Максимов, І. Сирватка, Р. Кабало, Н. Гатайло-Мазур, В. Гамар, Ю. Чумак, О. Кривозірка, А. Душний, М. Головчак [2]. У цьому закладі активно функціонує популярний «Прикарпатський дует баяністів», створений у 1982 р. заслуженим працівником культури України В. Чумаком (випускником Уральської консерваторії) та С. Максимовим $[6,124-132 ; 7,124-131]$. Учасники колективу здійснювали оригінальні авторські переклади класики та музичних творів сучасності, виступали у конкурсно-фестивальних акціях. Детально опрацювавши історичний та виконавський доробок колективу, А. Душний довів, зокрема, що «Прикарпатський дует баяністів» $\epsilon$ незмінною якісною складовою вітчизняної академічної школи народно-інструментального мистецтва, який підтверджує високу репутацію Львівської баянної школи $[3,10]$. Так, дует $\epsilon$ лауреатом міжнародних та всеукраїнських конкурсів (гастролював у Польщі, Англії, Італії, Канаді, Німеччині, Австрії). Сьогодні, визнаними в Україні та зарубіжжі постають новостворені народно-інструментальні колективи коледжу піж орудою представників школи. Серед них - ансамблі народної музики «Українські візерунки» під керівництвом В. Гамара, учасника мистецьких імпрез в Україні, Польщі, Словаччині та «Барви Карпат» під керівництвом С. Максимова, учасника урядових концертів та фестивальних програм в Україні, Японії, Польщі, Італії, Словаччині, Чехії [4, 48-49]. Керівники колективів - випускники класу А. Онуфрієнка. Саме педагогами-ентузіастами Дрогобицького училища було підготовлено благодатний грунт для формування майбутнього потужного конкурсного руху у баянноакордеонному виконавстві. На початку 1979 p. в Дрогобичі було проведено відбіркові прослуховування до Всесоюзного конкурсу баяністівакордеоністів. 16-18 березня 1989 р. за участі та ініціативи педагогів закладу було проведено 
Перший зональний конкурс учнів-баяністів училищ Західного регіону УРСР. На початку травня 1990 року тут відбувалися прослуховування на черговий всесоюзний конкурс та на міжнародний конкурс у Москві Важливість діяльності баянних класів не лише у мистецькому контексті закладу, але й регіону очевидна, 3 програми ювілейних заходів до 60-річчя училища (2005), де були задіяні як солісти лауреати міжнародних конкурсів С. Максимов, Ю. Чумак, лауреатка зонального конкурсу Н. Мазур, I. Сирватка, О. Кривозірка, «Прикарпатський дует» у складі В. Чумака та С. Максимова, а також Оркестр українських народних інструментів під керівництвом Ю. Чумака. На базі училища започатковано Всеукраїнський конкурс виконавців на народних інструментів імені Анатолія Онуфрієнка, який об'єднав виконавців (солістів, ансамблі, оркестри) усіх рівнів та ланок навчання України. У процесі змагань активно проводяться концерти й конференції, майстер-класи провідних фахівців народноінструментального мистецтва [5]. У творчому тандемі 3 відділом народних інструментів ДДМК, активно співпрацює кафедра народних музичних інструментів та вокалу Інституту музичного мистецтва Дрогобицького державного педагогічного університету імені Івана Франка [10]. Основу кафедри становить методичне об'єднання викладачів народних інструментів, яке створено у перші роки існування музично-педагогічного факультету під керівництвом випускника Львівської консерваторії, корифея баянного мистецтва Дрогобиччини професора Е. Мантулєва (1965-2004) [6, 116-123], згодом - кандидата педагогічних наук, доцента I. Фрайта (з 2004). Сьогодні на кафедрі активно працюють продовжувачі традицій Львівської школи Е. Мантулєв, А. Душний. Чумак, а також випускники факультету Є. Марченко, Б. Пиц, I. Фрайт, В. Шафета, В. Салій, А. Боженський, Р. Стахнів. Варто звернути увагу на наявність ще однієї авторської школи баянного виконавства та педагогіки - школи провідного педагога баянних класів у фахових навчальних закладах Дрогобича Ернеста Мантулєва. Музичний діяч сформувався як спеціаліст у баянному класі О. Зуєва та класі диригування М. Бакаєва у Дрогобицькому музичному училищі (1958), а згодом обидві спеціальності опановував у Львівській державній консерваторії ім. М. Лисенка (клас баяна М. Оберюхтіна, клас диригування О. Плаксюка, 1963). В подальшому, спадкоємність педагогічної школи наставника знайшла в діяльності талановитого педагога самобутній розвиток і послужила формуванню підвалин баянного мистецтва в регіоні. Далі педагогічна майстерність діяча відточувалась у Львівському музично-педагогічному училищі імені Ф. Колесси (де він працював як викладач баяна та керівник оркестру, 1958-1965), Дрогобицькому музичному училищі (викладав методику гри на баяні та інструментознавство, 1965-2003). ОднакнайбільшепропрацювавЕ. Мантулєвв Дрогобицькому педагогічному університеті на музично-педагогічному факультеті (1965-2009), як викладач (доцент - 1986, професор - 2006) класу баяна, організатор, учасник, керівник низки викладацьких та студентських ансамблів та оркестрів, голова методичного об'єднання викладачів народних музичних інструментів та голова художньої ради. Власні виконавські досягнення Е. Мантулєва відзначені насамперед у ансамблевому виконавстві, зокрема як концертмейстера заслуженого Прикарпатського ансамблю пісні і танцю «Верховина» (учасник міжнародного конкурсу IV-го Всесвітнього фестивалю молоді і студентів у Москві, 1957). Музикант вів активну концертно-гастрольну діяльність у складі дуету (Е. Мантулєв, Б. Зарайський, 1959-1963), митець входив до вищезгадуваного активно гастролюючого ансамблю «Прикарпатське тріо баяністів» (1965-1984), виступаючи на Дрогобиччині та інших містах регіону як самостійна одиниця, так і в супроводі камерного оркестру ДДМУ [7, 33-36]. У музичному житті Дрогобиччини вагому роль відіграють народно-інструментальні колективи Інституту музичного мистецтва Дрогобицького педагогічного університету, засновані і очолювані Е. Мантулєвим: оркестр народних інструментів «Ліра» (дипломант Всесоюзного фестивалю народної творчості, 1987), ансамблі «Гармоніка» i «Прикарпатські музики». Для цих колективів керівник здійснює аранжування, у яких велику увагу приділено баяну і як сольному інструменту, і як рівноцінному учаснику ансамблевого діалогу. Концертні програми наведених колективів включають різностильову програму: зразки класичної музики, оригінальні композиції та переклади Е. Мантулєва, 
фольклорні й естрадні твори. Упродовж 19651985 рр. на кафедрі довгий час функціонував ансамбль «Гармоніка» під керівництвом Е. Мантулєва. Ансамбль створений у 1965 р. на базі квінтету викладачів-баяністів С. Торічної, М. Сеньо, О. Ліщинського, В. Собка та Е. Мантулєва, на початку своєї виконавської діяльності виконував переважно аранжування власного керівника та засновника. Концерт колективу, який відбувся 8 травня 1985 року, транслювало Українське телебачення. Про нього у рецензіях преси («Радянський педагог») зазначено: «... колектив, керований від початку створення невтомним пропагандистом баянного мистецтва доцентом Е. I. Мантулєвим, є доброю школою, в якій педагоги мають змогу підтримувати музично-виконавський рівень, разом музикувати, і тим самим подають добрий приклад своїм вихованцям». Часопис також наголошував, що «всі твори оркестрував Е. І. Мантулєв» [16]. 31968 р. інструментальний колектив поповнили С. Процик (пріма), М. Фрайт (альт), В. Собко (баритон), Є. Марченко (контрабас) та виконавці на готово-виборних баянах: Е. Мантулєв, О. Ліщинський, В. Чумак. Введення до колективу тембрових гармонік дало можливість розширення діапазону, збільшення технічних можливостей i збагачення тембрової палітри ансамблю. 3 цим колективом Е. Мантулєв не лише концертував у Львові, Трускавці, Стрию, Івано-Франківську, але й здійснював записи на республіканському та Львівському телебаченні. 3 колективом виступали дрогобицькі майстри вокального мистецтва К. Сятецький, П. Турянський, І. Кліш, Л. Краєвська, Л. Радевич-Винницька. Студентський ансамбль «Прикарпатські музики» у складі: кларнет - Б. Колодій, акордеон - В. Шафета, гітара - П. Токар, контрабас - В. Чавва, створений у 2002 р., відрізняється тембральною різноманітністю та високими технічними можливостями. Серед його вихованців лауреати всеукраїнських та міжнародних конкурсів В. Бондаренко, О. Тудуй, Є. Коломієць, О. П'ятачук, В. Шафета, Г. Андрушко, заслужені працівники культури України С. Дацюк, П. Гушоватий, I. Мамайчук та ін. Так, окрім власної тривалої і плідної педагогічної праці у фахових навчальних закладах Львова та Дрогобича Е. Мантулєв став наставником кількох поколінь педагогів, які розви- нули його педагогічну концепцію в усіх ланках професійної спадкоємності. Вихідцями 3 його класу є професори О. Музальов, С. Димченко, доценти С. Торічна, Є. Марченко, С. Процик. Так, професор Станіслав Димченко є деканом факультету музичної творчості (1991) Рівненського Державного Інституту культури, деканом факультету музичного мистецтва (1999) Рівненського гуманітарного університету, де читає значний комплекс спеціальних дисциплін (основний та додатковий інструмент, диригування, оркестровий клас, курси «Методика викладання гри на музичних інструментах», «Методичні роботи над музичним репертуаром»). Керівник концертує з оркестром народних інструментів, з яким здійснив низку аудіозаписів. Фахівець-педагог $\epsilon$ автором низки навчальних програм, посібників, навчальнорепертуарних збірок, методичних рекомендацій, інструментувань та аранжувань для оркестру народних інструментів, розвідок з питань музичної педагогіки та музикознавства, публіцистичних нарисів у періодиці $[4,12-13]$. Представниками класу Е. Мантулєва $€$ викладачі Дрогобицької музичної школи № 1 Роман Ілик та його вихованець Роман Яворський, учні яких у ряді постійних представників конкурсних змагань юних виконавців на обласному конкурсі учнів старших класів виконавців на народних інструментах серед мистецьких шкіл Львівщини, для прикладу - на XI-у Всеукраїнському конкурсі «Провесінь», який проходив у місті Кіровоград, лауреатом III-го ступеня став учень Романа Яворського Володимир Муравський, а на I-у Міжнародному конкурсі «Акорди Львова» посів третє місце. На цьому ж Міжнародному конкурсі Диплом II-го ступеня завоював Роман Стахнів - учень Романа Ілика [9]. Окрім цього Роман Ілик - керівник Зразкового гурту «Прикарпатські музики», створеного у Дрогобицькій ДМШ № 1, 3 яким виступає на сценах Дрогобича, Борислава, Трускавця, Стебника, Львова, а також сіл району (всього близько 300 концертних виступів). У процесі виконавської діяльності, зазначає Р. Ілик: «... важливим $€$ комплексний підхід до збереження національних традицій народу та виховання підростаючого покоління на кращих зразках музичного мистецтва, які $є$ доступними для виконання дитячими колективами» [8]. Колектив неодноразово здобував призові місця на 
обласних та регіональних конкурсах та фестивалях, а у 2006 року Зразковий гурт «Прикарпатські музики» став володарем «Гран Прі» I-го Всеукраїнського конкурсу-фестивалю дитячо-юнацького музичного мистецтва «Кришталевий Трускавець» (м. Трускавець). Молодшу генерацію вихованців класів Е. Мантулєва та Д. Кужелєва представляє старший викладач кафедри народних музичних інструментів ДДПУ ім. I. Франка Валерій Шафета - багаторазовий лауреат регіональних та міжнародних конкурсів як соліст та у складі ансамблю «Retro» та вокальнохореографічного ансамблю «Пролісок». Музикант має багатогранний досвід співпраці з ансамблями різних вікових категорій, фахової підготовки та стильових орієнтирів: дитячого інструментального ансамблю «Лісові квіти», концертмейстер народної студентської капели «Gaudeamus», народного-інструментального ансамблю «Намисто», соліст-акордеоніст гурту «Дрогобицькі музики» $[10,24]$. Власне ансамблева творчість 3 баянами у складі є вагомою складовою його наукових інтересів, що знайшло відображення у низці розвідок $[12 ; 13 ; 14$; 15]. 3 огляду на виконавські потреби колективів, з якими він співпрацює, акордеоніст постає укладачем та редактором репертуарних збірок. Водночас, у Дрогобичі наявні й інші лінії продовження творчо-педагогічних принципів Львівської баянної школи. Так, активним організатором мистецького життя, наукового осмислення аспектів цієї школи, викладачем спеціального баянно-акордеонного класу є Андрій Душний, чия діяльність продовжує і розвиває лінію спадкоємності М. Оберюхтін - А. Онуфрієнко - С. Карась. У даний час А. Душний кандидат педагогічних наук, доцент кафедри народних музичних інструментів та вокалу Дрогобицького державного педагогічного університету ім. I. Франка, член-кореспондент Міжнародної академії наук педагогічної освіти, заслужений діяч естрадного мистецтва України $[10,12-13]$. Показовими є успіхи учнів класу А. Душного у творчих змаганнях різного рівня. Серед баянних студентських колективів Інституту музичного мистецтва ДДПУ ім. І. Франка дует акордеоністів - Ігор Куртий та Андрій Боженський (лауреати все українських та міжнародних конкурсів). Колектив неодноразово був відзначений на різноманітних творчих змаганнях. Цей дует та дует в складі дипломанта міжнародного конкурсу баяністів-акордеоністів Руслана Кундиса та лауреатки Всеукраїнського конкурсу ім. А. Онуфрієнка Ганни Андрушко, разом 3 ансамблями «Намисто» і «Пролісок» представляли національне музичне мистецтво в програмі урочистого концерту з нагоди Дня Європи в Україні 5 червня 2007 року. Ці ж колективи (окрім другого 3 названих дуетів) фігурують й у концертній програмі Міжнародної практичної конференції «Формування цінностей сучасної особистості» (20 вересня 2007 року). Серед виконавців-солістів - представників цього класу неодноразово лауреатськими званнями було відзначено Р. Стахніва, автора даного дослідження - Р. Кундиса, І. Куртого, А. Боженського, К. Коробко, В. Мицака, Ю. Ісевича, О. Сергієнко, Н. Хомина, Н. Федину, Г. Савчин, В. Бобанича, Г. Богомол, а також численні ансамблі за їх участі $[10,80-82]$. А. Душний проводить послідовну роботу з репертуарного забезпечення, укладає та редагує збірки дидактичної літератури, окрім цього він є автором низки перекладень для дуету баяністів та аранжувань для бандури й оркестру народних інструментів, здійснює формування та видання підручниково-посібникової літератури [3], методичних рекомендацій, довідникової літератури $[4 ; 10]$, редагування та анотування нотних видань, підготовка та ведення численних історико-музикознавчих телевізійних та радіопрограм, виступає упорядником наукових збірників та матеріалів конференцій [6; 7], активно публікується у фахових та наукових виданнях України та зарубіжжя, член журі національних та міжнародних конкурсів в Україні, Італії, Польщі, Литві, Латвії, Білорусії. Однією 3 найважливіших сфер його діяльності вирізняється мистецько-організаційна, як така, що спрямована на відродження та популяризацію кращих традицій школи в соціокультурному просторі України та зарубіжжя. Ініціативний музикант-баяніст, педагог та науковець $\epsilon$ автором ідеї та співзасновником науково-мистецьких проектів «Львівська школа баянноакордеонного мистецтва» (2005) та «Молода генерація Львівської баянної школи» (2008). Ініціатор та організатор численних науковопрактичних конференцій («Львівська баянна школа та їі видатні представники», «Народноінструментальне мистецтво на зламі $\mathrm{XX}$ XXI століть», «Музична освіта України - про- 
блеми теорії, методики, практики», «Творчість для народних інструментів композиторів України та зарубіжжя», «Музичне мистецтво XXI століття - історія, теорія, практика») та масштабних мистецьких форумів - Всеукраїнського Відкритого конкурсу баяністів-акордеоністів «Візерунки Прикарпаття» та Міжнароного конкурсу баяністів-акордеоністів «Perpetuum mobile» які щорічно проводяться на базі Франкового Вишу і об'єднюють виконавців із України та зарубіжжя. За його безпосередньої участі відбуваються найрізноманітніші концертні акції, які залучають до співпраці баяністів-виконавців й представників народно-інструментальної спільноти від початкуючих до провідних майстрів сфери народних інструментів України, представників української діаспори та зарубіжних гостей [11, 192, 200, 202-204].

Висновки. Отже, авторська школа М. Оберюхтіна стала центральною у творенні системи дочірніх авторських шкіл спеціалістів кількох генерацій Дрогобиччини. Їх комплексна багатовекторна реалізація створила підгрунтя для формування школи баянно-акордеонного мистецтва на Львівщині. На сьогодні вона $є$ сформованою регіональною інструментальною школою, яку відрізняє вагомість внеску в розвиток української культури і має загальнонаціональну цінність.

\section{ЛIТЕРАТУРА:}

1. Давидов М. Історія виконавства на народних інструментах (українська академічна школа) : підр. [для вищих та сер. муз. навч. закл.]. Київ : НМАУ ім. П. І. Чайковського, 2010. - 592 с.

2. Дрогобицькому державному музичному училищу імені Василя Барвінського - 60. Дрогобич : Коло, $2005.80 \mathrm{c}$.

3. Душний А. Прикарпатський дует баяністів - творчо-виконавський аспект : навч. пос. Дрогобич : По́світ, 2007. 88 c.

4. Душний А. Львівська школа баянно-акордеонного мистецтва : довідник. Дрогобич : По́світ, 2010. 216 с.

5. Имханицкий М. Первый Всеукраинский конкурс исполнителей на народных инструментах имени Анатолия Онуфриенко. Народник (Москва). 2007. № 3 (59). С. 60-61.

6. Львівська баянна школа та їі видатні представники (70-річчю від дня народження А. Онуфрієнка присвячується) : зб. мат. наук.-практ. конф. / [упоряд. А. Душний, С. Карась, І. Фрайт]. Дрогобич : Коло, 2005. 148 с.

7. Львівська баянна школа та ії видатні представники. Михайлу Оберюхтіну присвячується : зб. мат. міжн. наук.-практ. конф. / [ред.-упоряд. А. Душний, С. Карась, Б. Пиц]. Дрогобич : По́світ, 2006. 160 с.

8. Михаць М. Вчитель музики - організатор дитячого фольклорного колективу. 3 педагогічного досвіду роботи керівника зразкового гурту «Прикарпатські музики» Романа Ілика (м. Дрогобич). Молодь і ринок : щоміс. наук.пед. журнал. 2007. № 3-4 (26-27). С. 105-110.

9. Михаць М. Обдарована молодь робить успіхи / М. Михаць // Мій Дрогобич. 2008. № 17 (151). 27 квітня. четвер.

10. Пиц Б. Кафедра музичних інструментів та вокалу Дрогобицького державного педагогічного університету імені Івана Франка : Науково-історичний довідник [гол. ред. І. Фрайт]. Дрогобич : По́світ, 2011. 196 с.

11. Семешко А. Баянно-акордеонне мистецтво України на зламі XX - XXI століть : довідник. Тернопіль : Навчальна книга «Богдан», 2009. 244 с.

12. Шафета В. Виконавські склади та репертуар мішаних баянних ансамблів Львівщини. Музикознавчі студії інституту мистецтв Волинського національного університету імені Л. Українки та Національної музичної академії України імені П. І. Чайковського : зб. наук. пр. / [упоряд. О. І. Коменда]. Луцьк : Волин. нац. ун-т ім. Лесі Українки, 2010. Вип. 6. С. 145-154.

13. Шафета В. Внесок керівників ансамблів народних інструментів Львівщини у виконавський репертуар, музичну науку і публіцистику. Наукові записки Тернопільського НПУ ім. В. Гнатюка. Серія : Мистецтвознавство. 2010. № 1. C. 110-114.

14. Шафета В. Інструментальне ансамблеве мистецтво Дрогобиччини : музично-педагогічний факультет ДДПУ ім. I. Франка. Історія, теорія та практика музично-естетичного виховання : зб. наук. мат. IV-го Всеукр. наук.-практ. семінару. Дрогобич : По́світ, 2010. С. 242-245.

15. Шафета В. Соціокультурне значення ансамблевого мистецтва Львівщини за участю баяна-акордеона у естрадних, фольклорно-академічних, академічно-професійних та самодіяльно-аматорських колективах. Народноінструментальне мистецтво на зламі XX-XXI століть : зб. мат. III-ї Всеукр. наук.-практ. конф. (ДДПУ ім. І. Франка, 19.03.10) / [ред.-упоряд. А. Душний, Б. Пиц]. Дрогобич : По́світ, 2010. С. 97-103.

16. Яцків О. На телебаченні «Гармоніка». Радянський педагог. 1985. 13 червня. четвер. 


\section{REFERENCES}

1. Davydov M. Istoriia vykonavstva na narodnykh instrumentakh (ukrainska akademichna shkola) : pidr. [dlia vyshchykh ta ser. muz. navch. zakl.] / M. Davydov. - K. : NMAU im. P. I. Chaikovskoho, 2010. $592 \mathrm{~s}$.

2. Drohobytskomu derzhavnomu muzychnomu uchylyshchu imeni Vasylia Barvinskoho - 60. Drohobych : Kolo, 2005. $80 \mathrm{~s}$.

3. Dushniy A. Prykarpatskyi duet baianistiv - tvorcho-vykonavskyi aspekt : navch. pos. Drohobych : Pósvit, 2007. 88 s.

4. Dushniy A. Lvivska shkola baianno-akordeonnoho mystetstva : dovidnyk / A. Dushniy, B. Pyts. Drohobych : Pósvit, 2010. $216 \mathrm{~s}$.

5. Ymkhanytskyi M. Pervыi Vseukraynskyi konkurs yspolnytelei na narodnыkh ynstrumentakh ymeny Anatolyia Onufryenko. Narodnyk (Moskva). 2007. № 3 (59). S. 60-61.

6. Lvivska baianna shkola ta yii vydatni predstavnyky (70-richchiu vid dnia narodzhennia A. Onufriienka prysviachuietsia) : zb. mat. nauk.-prakt. konf. / [uporiad. A. Dushniy, S. Karas, I. Frait]. Drohobych : Kolo, 2005. 148 s.

7. Lvivska baianna shkola ta yii vydatni predstavnyky. Mykhailu Oberiukhtinu prysviachuietsia : zb. mat. mizhn. nauk.-prakt. konf. / [red.-uporiad. A. Dushniy, S. Karas, B. Pyts]. Drohobych : Pósvit, 2006. 160 s.

8. Mykhats M. Vchytel muzyky - orhanizator dytiachoho folklornoho kolektyvu. Z pedahohichnoho dosvidu roboty kerivnyka zrazkovoho hurtu «Prykarpatski muzyky» Romana Ilyka (m. Drohobych). Molod i rynok : shchomis. nauk.-ped. zhurnal. 2007. № 3-4 (26-27). S. 105-110.

9. Mykhats M. Obdarovana molod robyt uspikhy. Mii Drohobych. 2008. № 17 (151). 27 kvitnia. chetver.

10. Pyts B. Kafedra muzychnykh instrumentiv ta vokalu Drohobytskoho derzhavnoho pedahohichnoho universytetu imeni Ivana Franka : Naukovo-istorychnyi dovidnyk. [hol. red. I. Frait]. - Drohobych : Pósvit, 2011. $196 \mathrm{s.}$

11. Semeshko A. Baianno-akordeonne mystetstvo Ukrainy na zlami KhKh - KhKhI stolit : dovidnyk. Ternopil : Navchalna knyha «Bohdan», 2009. 244 s.

12. Shafeta V. Vykonavski sklady ta repertuar mishanykh baiannykh ansambliv Lvivshchyny. Muzykoznavchi studii instytutu mystetstv Volynskoho natsionalnoho universytetu imeni L. Ukrainky ta Natsionalnoi muzychnoi akademii Ukrainy imeni P. I. Chaikovskoho : zb. nauk. pr. / [uporiad. O. I. Komenda]. Lutsk : Volyn. nats. un-t im. Lesi Ukrainky, 2010. Vyp. 6 S. 145-154.

13. Shafeta V. Vnesok kerivnykiv ansambliv narodnykh instrumentiv Lvivshchyny u vykonavskyi repertuar, muzychnu nauku i publitsystyku Naukovi zapysky Ternopilskoho NPU im. V. Hnatiuka. Seriia : Mystetstvoznavstvo. 2010. № 1. S. 110-114.

14. Shafeta V. Instrumentalne ansambleve mystetstvo Drohobychchyny : muzychno-pedahohichnyi fakultet DDPU im. I. Franka / V. Shafeta // Istoriia, teoriia ta praktyka muzychno-estetychnoho vykhovannia : zb. nauk. mat. IV-ho Vseukr. nauk.-prakt. seminaru. Drohobych : Pósvit, 2010. S. 242-245.

15. Shafeta V. Sotsiokulturne znachennia ansamblevoho mystetstva Lvivshchyny za uchastiu baiana-akordeona u estradnykh, folklorno-akademichnykh, akademichno-profesiinykh ta samodiialnoamatorskykh kolektyvakh. Narodnoinstrumentalne mystetstvo na zlami KhKh-KhKhI stolit : zb. mat. III-yi Vseukr. nauk.-prakt. konf. (DDPU im. I. Franka, 19.03.10) / [red.-uporiad. A. Dushniy, B. Pyts]. Drohobych : Pósvit, 2010. S. 97-103.

16. Iatskiv O. Na telebachenni «Harmonika» Radianskyi pedahoh. 1985. 13 chervnia. chetver. 